\title{
Urban Globalization and its Historicity: The Case of the Global Sanitary City in Mexico in the Nineteenth Century
}

\begin{abstract}
Medicine and sanitary engineering were applied gradually during the nineteenth century as solutions to the terrible conditions of life and habitat that prevailed in the cities of the capitalist world-but also with the purpose of regenerating the human work force necessary to reproduce wealth. This essay shows how this global sanitarian effort was applied in Mexico City during the government of President Porfirio Díaz (1876-1880, 1884-1910), exemplifying the conceptions and prejudices about health, disease, environment and urban government shared by Mexican elites and their international peers, and with which they justified reforms aimed at controlling and disciplining nature and the social environment.
\end{abstract}

During the inaugural ceremony of the Mexico Valley drainage system on March 17, 1900, Mexico's president General Porfirio Díaz-on his fifth term in office-declared it "such an important and transcendent occasion for our future that it has to be registered in the annals of the Mexican people beside and the same level of our independence day" ("Una de las más grandes fiestas del progreso. Inauguración de las obras del Desagüe”, El Popular, México City, 19/3/1900). The Drainage Project, set out in 1886, consisted of a main conduit $47.58 \mathrm{~km}$ long and between 5 and 21 meters in depth, which spanned from the San Lázaro gate through the Guadalupe range towards Lake Texcoco, where it twisted towards the west, traversing diagonally Lake San Cristóbal and a portion of Lakes Xaltocan and Zumpango, to finally connect to the ovoid (10,021 meters long, 4.28 meters high and 27-98 meters deep) Tequisquiac tunnel, through which the waters flowed through the Tequisquiac river and finally to Atilalaquia, to be used to generate power and irrigate land in Actopan, in Hidalgo state. Residual waters went to the Tula River, a branch of the Pánuco River, from which it flowed into the Gulf of Mexico, south of Tampico. Its main goal was apparently to get Mexico City's water and sewage out of the valley, while preserving the valley's drinkable water.

Sergio Miranda Pacheco, Universidad Nacional Autónoma de México (UNAM)

Ә OpenAccess. (C) 2018 Sergio Miranda Pacheco, published by De Gruyter. ((c))BY-NC-ND This work is licensed under the Creative Commons Attribution-NonCommercial-NoDerivatives 4.0 License. https://doi.org/10.1515/9783110492415-017 
In the mindset of the Mexican president, the significance of such a gigantic hydraulic infrastructure being tantamount to that of Mexico's independence, doubtless stemmed from the fact that both enterprises had liberated the Mexican people from, on the one hand, oppression from the Spanish Empire and, on the other hand, from material harm to its health and prized possessions from the constant flooding that for centuries ravaged Mexico City and other nearby valley communities. Consequently, from this standpoint, at the onset of the twentieth century, Mexicans faced a very promising future: they belonged to a sovereign and independent nation, and under Díaz's leadership, they had vanquished the dictatorship of the environment, thus placing themselves in the sphere of progress and modernity, just like the United States and any nation in Europe. Henceforth, Mexico would have the modern water supply and disposal systems required to improve the material state of public health in the capital.

Yet, from another standpoint, the conception and completion of the Mexico Valley drainage works may be interpreted as an updating and modernization of a material, technical and environmental scheme supported by an absolute political power (such as Díaz's), through which the elites had since colonial times enforced and tried to control the social, political and environmental milieu, so as to reproduce and increase the own wealth along with the income of their firms, situated in Mexico City and allied to the regional, national and global markets. By then, urbanization had become capitalism's main force for economic, social, political and environmental change, and cities were not just stages of capitalist modernization, but means and gears of the new globalization of wealth making.

Nevertheless, driven by the recent industrial development of production systems and the dramatic impoverishment of workers and peasants upon which it stood, throughout the nineteenth century cruel realities dwelt within cities, constituting severe conflicts and threats to the reproduction of capitalist wealth. Along with class conflicts, political struggles and revolutionary outbreaks, nineteenth-century elites agonizingly lived and faced the conflict between health and wealth existing in most countries, as the world raced toward an urban civilization during the nineteenth century.

As Bruno Latour says, by the middle of the century the battle between health and wealth had reached a breaking point:

The consumption of human life as fuel for wealth production led, firstly on English cities and henceforth on other European cities, to an actual energy crisis. Men, as it was often and widely stated, were of bad quality. That could not go on. Cities could no longer be death chambers and sewers, neither do the poor go on being miserable, ignorant, surrounded by vermin and infectious vagrants. The reactivation and broadening of exploitation (or prosperity, for that matter) demanded a better educated and cleaner population, well ven- 
tilated, as well as rebuilt cities, with drains, fountains, schools, parks, gymnasiums, clinics, nurseries. (following Latour 1988, p.18)

Medicine and sanitation engineering were thus the gradual solution to end the dire habitat and living conditions in cities across the capitalist world; but likewise to revive the human workforce vital for reproducing wealth, as health and urban policies helped to consolidate the social and spatial segregation that existed in cities since the ancien regime.

In this context we can interpret the completion of the Mexico Valley drainage works implemented by the Díaz government as part of the expansion of the health-oriented urban model of capitalism. As we will try to demonstrate in the following pages, Mexican elites shared with their pairs from other countries certain concepts about health, disease, the environment and urban government by which they justified reforms that imposed control and discipline on both nature and the social milieu.

\section{Sanitary urbanization}

During the nineteenth century, certain technological advances made possible the wild urbanization of the planet, or, in other terms, the wild colonization of nature. One of these technological developments was the removal of the wastewater produced by workshops, industries and homes in cities, which could be collected and later expelled from the urban milieu, as demanded by the principles of urban hygiene then in vogue. Such principles, along with their technological groundwork, were also supported by social, cultural and historical perceptions about human waste. In certain Asian countries and in Medieval Europe, at least until the eighteenth century, human feces and urine were used advantageously in crops and workshops, until people became prejudiced against their look and scent. In those times, as stated by Verena Winivarter, human litter was regarded as a useful (albeit foul-smelling and ugly) resource for farming and industry, and not dreadful trash or waste that had to be hidden from sight and evicted from the city, in accordance with the morals of nineteenth-century industrialized societies in which a new social and urban order was institutionalized, bound to public health medical and sanitary policies. Drainage became thus the technological vehicle for promoting the healthy, but also comfortable, urban life demanded by the new capitalist bourgeoisie (Winiwarter 2010).

Vienna, Paris, London and Venice, as Alexander Cowan and Jill Steward posit, were capital cities that in the nineteenth century instilled their spaces 
and population with a strong trade and management activity, as well as with public rituals, and thus with an intense and spectacular cultural dynamism unseen in lesser cities. Likewise, capital cities enticed huge crowds of immigrants, hence nourishing the cultural and social inequalities cast upon the social layout of their spaces. In time, their growth brought about major changes in the urban environment, and physical and demographic expansion furthermore affected the sensorial experience significantly. The stresses on space came from the development of industrial activity that made towns denser, intensified assorted olfactory experiences and forced authorities to intervene by controlling foul smells and fecal waste (Cowan and Stewart 2007, pp. 9-10).

When modern drainage systems were introduced in Europe's capitals and main cities by mid-nineteenth century, the thinking on public health was dominated by the miasma theory, according to which wastes and foul stenches were the main cause of disease (Schott 2004). For centuries, the 'pestilence' was regarded as an illness that fouled the air, soil, water, animals and men. Its causes, symptoms and treatment were identified by fifteenth century physician and philosopher Marsilio Ficino, founder of Florence's Platonic Academy. According to him:

[Whenever visible and tangible] the air of that place leaves its nature, declining from hot and humid, when there are many dense clouds, dust clouds, dense and hot wind [...]; when fields and water turn into steam and emit a foul smell, fish do not taste or smell good; there is an abundance of animals breeding in corruption, foul funguses and pastures, fruits of the land and insipid animals, and stored for very little time; wines tend to become muddy, animals escape and birds fly away; disease ensues with continuous, hidden, furious, deceitful, unusually hot fevers, with suffering of the chest, exhaustion of the pulse, agitation, darkened urine, skinning of the palate and the intestines, stinging in the eyes, worms, smallpox and measles, miscarriages and stillborn babies, rages, wild laughter, cruel wars and quite new miracles of nature or God. (Ficino 1564, p. 50)

Therefore, it was high time to run away-and for a long time-from places and spaces wherein the hints of 'pestilence' were obvious. Moreover, it was best to do so at the first warning, because if one should linger further, there was a risk of contagion by 'someone injured' or "that the quality of that air would become familiar and almost natural." The suitable place to escape to was wherever no person or thing infected by the pestilence was present and, if possible, "where there is neither sound, listened or felt, nor news from the spoiled place, and there are high mountains to forestall the fumes from coming either through the incoming wind or air to spread the poison.”

How feasible were Marsilio's recommendations? In early modern cities, families from the nascent bourgeoisie could perhaps follow them. Getting away from 
the sources of pestilence meant having resources to travel and sustain oneself at the chosen place, either temporally or definitely, besides covering the expenses entailed in getting a cure. For many, the only option was staying put, hoping that luck or God's will ('the only safe and true health,' according to Ficino) would free them from the pestilence's onslaught.

Nonetheless, cities grew in size and population, and so their authorities and inhabitants had to take measures to prevent diseases and fight their probable causes-mainly corruption of the air brought by emissions from foul stagnant water, in addition to animal and human feces. Even though physicians who faced the sixteenth and seventeenth century plagues in the western Mediterranean cities believed that animals (besides the poor) were the source of infection, the circulation of water and air was the guideline for medical practice both in European and in American cities since the sixteenth century (Villar 2005; Valderrama 2005). The city was then regarded as an organism, whose health largely depended on the flow and expulsion of filthy water and air from graveyards, landfills, canals and sewer mains, filled with mud, feces, carcasses, and generally, with refuse from hospitals, convents, churches, slaughterhouses, farmyards, tailor shops, taverns and inns.

Although bacteriology disproved the miasma theory by the 1880s, belief in the adverse effects of bad odors on health remained dominant across Europe and the rest of the world well into the twentieth century, as could be seen in the importance bestowed upon scrubbing streets and introducing tap water and water closets in households. Technical advances in sanitation engineering -like those devised by Sir Joseph Bazalgette in mid nineteenth-century London (Halliday 1999), or those made in Paris (Barnes 2006) in the latter part of the century-to expel refuse and waste out of the urban environment enticed other cities into adopting water and sewer systems, which eventually were integrated into a comprehensive water supply and disposal system, which was in turn quite successful in improving urban cleanliness and reducing water-transmitted diseases (Schott 2004; Melosi 2008).

So, Ficino's recommendation of leaving the city to escape from the plague and preserve health became moot by the early twentieth century. Conversely, bacteriology and its ally, sanitary engineering, fought against popular beliefs regarding the origin of diseases and the ways to treat them, and sponsored a new reordering of the urban space, thereby rendering old and traditional waste disposal and recycling systems in garden and farmlands obsolete.

However, the battle against rubbish that cities were winning did not take into consideration the negative offshoots on the environment the expulsion of refuse would have, both on the cities themselves and on those lands and rivers that would collect and store the garbage. Worse still, changes in the urbanites' 
mindset, habits and culture would finally cause a major unanticipated environmental impact. Energy and resource consumption (and depletion) for every city dweller grew dramatically. To satisfy such demand, it became necessary to increase spending on infrastructure and maintenance, as well as taxes, besides rises in the prices of houses, rents and urban land. All of this would strengthen, in the end, the very longstanding social inequalities that the modernization of the water supply and sewer system was supposed to eradicate.

\section{Mexico City and its valley: drainage and power in the nineteenth century}

In nineteenth century Mexico City, sanitation works to preserve and improve health conditions for its inhabitants had to be undertaken on several levels. Cleaning up streets, rivers, ditches, canals and water mains within the city, in addition to rivers, land and lakes in the surrounding valley became paramount, since stagnant water and sewage were deemed the main cause of the infectious diseases that repeatedly struck the population throughout the century. Natural conditions of soil and climate in the valley and city made that stagnation possible. On the one hand, according to Manuel Orozco y Berra, the Mexico Valley spanned across a vast extension of land situated at the center of a mountain range then called Anahuac. This range limited the valley to the north, wherein the terrain rose to form huge hills that merged with those of the Pachuca and Atotonilco ranges.

The structure of the soil and the influence of volcanic activity created a pond into which the northern mountains spilt their waters. However, this natural draining was finally closed due to geological action, thus forming a lake system in the middle of which the Indian city of México Tenochtitlan would eventually be built. There were several lakes in the Mexico Valley (as opposed to the city) whose surface was unstable. In 1864, the southern lakes, Chalco and Xochilmilco, measured 5.98 and 2.68 leagues respectively; to the east was Texcoco (10,395 leagues); and to the north, San Cristóbal (0.63), Xaltocan (3.08) and Zumpango (0.98). Those lakes did not have fixed boundaries. During the rainy season, the water level rose quickly and it spilled over a wide even plain that seemed like a wide basin, but which was not so, since during the dry season water evaporated or was absorbed into the land, and consequently the basin almost disappeared.

In particular, the Texcoco Lake was the most unstable. Since the terrain that surrounded it to the west was almost flat and very shallow, deposits, torrential 
rains and different water flows that spilled into it could flood the city; sometimes it was enough just for the wind to blow from the west to flood the basin. Afterwards, water leaked and flowed back into the center: "it was not odd that the place now swamped tomorrow might be located at a distance of three to four thousand meters from the lake shore." (Orozco y Berra 1864, pp. 108-115) In times of torrential rains, the southern lakes of Chalco-Xochimilco also threatened to leak water into the city and engulf it, which happened more than once.

Given the purposes for which the Mexico Valley drainage system was planned in the seventeenth century, it could drain the water from these lakes out of the valley as well as sewage from the city out of the Texcoco Lake basin. However, the works took too long, due to stoppages. It wasn't until the 1880s that they were resumed and they were finally finished in 1900. Meanwhile, flooding and the pestilence, ensuing from stagnant water and putrid sewage in the summer, besides the dust storms that carried rotting particles, constantly threatened the people's health.

Regarding Mexico City's drainage, it must be said that throughout the century, it suffered from severe flaws, as the canals were in utter disrepair and were not at the same level as the Texcoco Lake. Overall, small street canals at ground level performed the city's drainage; there were oriented from west to east, being the direction from which the terrain slanted more regularly, whereas from north to south the pitch was more variable and less pronounced.

In the downtown streets, the canals were 2.5 feet $(\mathrm{c} .76 \mathrm{~cm})$ wide and 5.5 feet (c. $1.67 \mathrm{~m}$ ) deep. At the upper part they were covered, but they also had several openings through which garbage used to slip and from which rotting matter oozed. The waters went to the Square Ditch (Zanja cuadrada), exiting to the canal crisscrossing the city, the Paseo de la Viga, which took them to the San Lázaro gate, and then toward the Texcoco Lake where they ended up after accumulating all the refuse the population had littered into them. Beyond the downtown area, the canals were irregular. They were mostly rough, makeshift, exposed, uneven gullies-some so deep and wide they hindered traffic and flooded streets with putrid fecal matter.

According to M. L. Smith, an American engineer, in 1848 the transit of liquid matter through the canals stalled, because the elevation of the city's ground floor in relation to the surface of Texcoco Lake was quite short. The distance from the Main Square (now called Zócalo) to the point where the water was dumped in the lake was 6.5 feet (c. $1.98 \mathrm{~m}$ ), but from the point where the city water drained into the Canal de la Viga, near the San Lázaro gate, the elevation was barely 3 feet $($ c. $0.91 \mathrm{~m})$ in relation to the lake. Therefore, the bottom of the canals were barely one foot over the lake's level, hardly two feet below the canal water that drained into the lake. As a result, the canals were always filled with a 
semifluid muck that released 'noxious miasmas,' harbingers of the city's and the valley's unhealthiness.

Because of its malfunction, throughout the century, the city and valley drainage was regarded as the cause of the insalubrity and pestilence that the people suffered. However, despite the fact that there were other political, economic, institutional, educational, social and environmental realities that deserved to be attended to in order to solve this very complex problem, neither citizens nor authorities had a comprehensive picture of the reasons for the unhealthiness of the city and valley, nor consequently an outlook on a long-lasting solution. Every authority, either local or federal, and every social or professional sector had their own, often biased, perceptions of the causes and the likely solutions that the city's insalubrity demanded.

Even though the 1604 master plan contemplated draining the valley lakes, by the mid-nineteenth century new projects, based on studies and experiences from other cities, offered, on the other hand, to restore and preserve the valley's hydrological balance, while avoiding flooding and further health hazards. However, a centralized political power structure-displayed in the figures of Austrian Emperor Maximilian of Hapsburg (who ruled Mexico from 1864 to 1867), and presidents Benito Juárez (1858-1872) and Porfirio Díaz (1876-1880; $1884-$ 1910)-combined with urbanization projects underwritten by foreign investment and promotion of pasteurization, forced upon public opinion the idea that draining the valley was the solution that the government and society's expectations had to look forward to. Lack of resources, in addition to the indolence and discord of authorities and the community, also helped to further this idea.

This was endorsed by the medical, engineering, geographical and farming guilds gathered at the 1878 Medical Congress-even though one year earlier another physician, José María Lobato, reporting on the positive results of 17 years of studying the problem, recommended the preservation of the city's and the valley's hydrological balance in order to eradicate epidemics and favor agriculture. In his studies, Lobato stated that he replicated Hans von Pettenkoffer's experiments of years earlier in Munich, where the medical community and municipal authorities had successfully adopted them in their struggle against typhus. According to Lobato:

In Mexico as in Munich, the quantity of rainwater fallen during the rainy season and distributed proportionally on a monthly basis must be perfectly related to what flows through the underground veins of the haulage terrains within the city's groundwork. If the hydrological balance were looked after, typhus would disappear since organic matter that cover the soil would not decompose or be uncovered; otherwise, typhus will appear. [Pettenkoffer] infers that the miasmatic principle causing typhus is absorbed or fixed on the surface permeable layers of the ground, and when the drop in the groundwater level un- 
covers these layers, typhus appears with the assorted pathological forms we know (José María Lobato, "Estudio higiénico sobre el tifo exantemático", Gaceta Médica de México, 1/2/1877).

However, it was too late to override the scientific consensus obtained by the Mexican government, which rather than sanction a scientific-environmental truth, actually authorized the conclusion of the works to drain the Mexico Valley. The new Diaz government deemed crucial to pursue the urban, social, political and economic reforms needed to discipline and control not just the water from rivers, canals and lakes, as well as waste water from the city, but especially the city's dwellers, and bound their fate to the same processes of modernization with which the major capital cities in Europe and the United States were experimenting. Liberals and conservatives had ceaselessly criticized the city's unhealthy conditions, and the regime supported by both factions throughout the nineteenth century promoted urbanization and favored private urban business ventures; so for them, continuing the valley's drainage works was essential.

In the 1870's (in particular since the beginning of the Diaz regime) the city's expansion and urbanization tended to accelerate at an even and sustained pace, being the outcome of the public and private interests and projects regarding real estate and urban land that began decades earlier, even before independence. As soon as the American invasion ended in 1848, several urbanization projects were set forth on land west of the city-thought the most suitable, as it was the least exposed to flooding, being on higher ground-in order to build new urban neighborhoods and set railway tracks between the city and other valley townships. Some were indeed built, but Maximillian's imperial government, though it launched manifold urbanization projects planned by both the oligarchy and the emperor himself, hesitated in adopting the draining of the valley.

As the valley dried out-a process sanctioned and legitimized as a scientific and urgent necessity by the 1878 Medical Congress-urbanization projects multiplied during the Diaz regime, becoming a juicy business that the revolutionary government took over and sustained. Lawyers and engineers, architects and physicians, were the professional groups leading the political, material, health and environmental changes the valley and the city experienced during the nineteenth century, and their power and influence spanned across the entire country, the twentieth century and the regimes established by the Mexican Revolution.

During the nineteenth century, these professionals, both as individuals and as a group, disparaged the municipalities' anachronism and inability to establish an orderly and healthy urban regime, denounced the squalor and immoral habits of the poor in the press, demanded the draining of the valley and the city, and benefited politically or economically, through occupying positions of author- 
ity or being related to them, from the reforms to urban and rural property. They demanded and wrote projects for social, healthcare and penal control, and authorized and planned huge real estate developments on the land west of the city, so as to move to where the city was least unhealthy. Meanwhile, the rest of the population, incapable of buying a land plot on which to build their own houses, went to live in old houses and neighborhoods downtown, or on plots already dried out in the east, where the federal and local government and business interests allowed the construction of illegal, very unhealthy tenements. Therefore, by the end of the Porfirian Age, as the draining of the valley was over, spatial segregation was evident in many of the capital's quarters.

The decision to drain the valley was purportedly made by the colonial regime to protect New Spain's capital from floods, but actually became a way to exploit and expropriate natural resources as well as peasant land within the valley, whose communities had preserved the necessary hydrological balance to sustain themselves for generations. As proven by Eva Candiani (2015), the drainage works' purposes and uses put New Spain in the reproduction sphere of a worldwide capitalist system. Nineteenth century liberal and conservative regimes maintained the drainage works' original purpose, as well as the reproduction of the capitalist interest of a new national urban, liberal and conservative elite, solidly related, politically, economically, urbanistically and morally to foreign oligarchies, especially those of the United States, France, the United Kingdom, Spain and Germany.

Even though the colonial drainage had affected the valley's hydrological and social balance (and consequently the health of the population) deeply, during the nineteenth century, some engineers (M. L. Smith, Gargollo, Orozco y Berra, Río de la Loza) and physicians (Lobato) scarcely discussed the inconvenience and harm to the environment and the people's health the full draining of the valley would cause. From their standpoint, the restoration, repair and expansion of the old draining system, both in the city and the valley, might have helped to reestablish the now-lost environmental balance, in addition to improving the housing and health of the city's increasingly impoverished population, which would have helped create a less adverse urban environment.

However, Mexico's wars and conflicts, and the interests the winning side forced upon the direction of national affairs, as well as the fears and prejudices regarding the origin and effects of the diseases that secularly ravaged the health of the inhabitants of the valley, were in favor of draining it. Certainly, as the century progressed, fear of flooding subsided as riverbeds and lakebeds dried offbut at the same time, health hazards began to grow. The correlation between both phenomena could barely be understood, when at the close of the century a new correlation emerged: as the city's population grew, socio-environmental 
prejudices developed regarding the causes of the valley and the city's unhealthiness. In that context, the discourse of physicians and engineers was used to sanction an environmental policy based upon elements not discussed or debated enough within the circle of the scientific community of the age. However, seduced by power, it supported draining the valley and thus a bourgeois environmental dream became a nightmare.

\section{Bibliography}

Barnes, David S. (2006): The Great Stink of Paris and the 19th Century Struggle Against Filths and Germs. Baltimore: The John Hopkins University Press.

Cowan, Alexander and Stewart, Jill (Eds.) (2007): The City and the Senses: Urban Culture Since 1500. Farnham (UK): Ashgate Publishing Company.

Ficino, Marsilio (1564): Libro compuesto por el famoso y singular philosopho, y gran médico [...] en el qual se contiene grandes ausos y secretos marauillosos, assi de medicina como de cirugia para curar y prefervarse los habres de pestilencia [...]. Caragoça: Printed in the home of Bernuz, Pedro, by Curteti, Francisco, who translated it from Florentine [originally published in 1469].

Halliday, Stephen (1999): The Great Stink of London. Sir Joseph Bazalgette and the Cleansing of Victorian Metropolis. Stroud (UK): Sutton Pub. Ltd.

Latour, Bruno (1988): The Pasteurization of France. London: Harvard University Press.

Molina del Villar, América (2005): “Las prácticas médicas y sanitarias en la ciudad de México 1736 -1739”. In: Estudios del Hombre, Universidad de Guadalajara, No. 20, pp. 39-58.

Orozco y Berra, Manuel (1864): Memoria para la carta hidrográfica del Valle de México. México: Imprenta de A. Boix.

Vázquez Valderrama, Jorge (2005): Ciudad, miasmas y microbios. La irrupción de la ciencia pasteuriana en Antioquia. Medellín: Universidad de Antioquia.

Schott, Dieter (2004): “Urban Environmental History: What Lesson are there to be learnt?" In: Boreal Environmental Research, 9, pp. 519-528.

Winiwarter, Verena (2001): "Where did all the waters go? The Introduction of Sewage Systems in Urban Settlements". In: Bernhardt, Christoph (Ed.): Environmental Problems in European Cities in the 19th and 20th Century. Munster,New York, Munich, Berlin: Waxman, pp. 105-119. 
